引用格式:孙康,季建文,李丽丹,等. 基于非期望产出的中国海洋渔业经济效率评价与时空分异 [J]. 资源科学, 2017,39(11): 2040-2051. [Sun K, Ji J W, Li L D, et al. Marine fishery economic efficiency and its spatio-temporal differences based on undesirable outputs in China[J]. Resources Science, 2017,39(11):2040-2051.] DOI: 10.18402/resci.2017.11.03

\title{
基于非期望产出的中国海洋渔业经济效率评价 与时空分异
}

\section{孙 康 ${ }^{1}$, 季建文 ${ }^{1}$, 李丽丹 ${ }^{1}$, 张 超 $^{1}$, 刘峻峰 ${ }^{2}$, 付 敏 $^{1}$}

(1. 辽宁师范大学海洋经济与可持续发展研究中心, 大连 116029 ;

2. 华东师范大学经济学院, 上海 200241)

\begin{abstract}
摘 要: 鉴于污染指标的不易测度,前人研究海洋渔业经济时极少从定量角度关注非期望产出。本文以海洋 天然渔业水域污染所造成的负效应作为非期望产出, 采用 SBM(Slacks Based Measure)模型, 对2004-2015年中国 沿海 11 个省市区的海洋渔业经济效率进行评价, 在此基础上采用 Kernel 密度和 Tobit 模型分析各省市区海洋渔业 经济效率时空演化格局及其影响因素。研究结果表明: (1) 基于时间序列视角, 中国海洋渔业经济效率值持续低迷, 说明近年来中国海洋渔业经济转型升级规制尚未发挥预期的效果; (2)基于时空视角, 中国沿海 11 个省市区的海洋 渔业经济效率呈现两极分化态势, 且未得到有效改善,说明中国沿海地区渔业经济发展水平失衡; (3) 基于全局视 角, 中国海洋渔业经济效率整体偏低, 说明中国海洋渔业经济发展速度较迟缓; (4) 基于产业结构视角, 第一产业比 重过高是影响中国整体海洋渔业经济效率持续走低的主因, 技术水平偏低是影响海洋渔业经济效率的关键, 说明 中国海洋渔业产业结构继续沿用传统的以第一产业为主的模式在运行。为扭转渔民就业专业化水平与效率的负 向关系, 渔业转产转业政策需提质增效。未来中国海洋渔业经济转型面临体制转型和结构转型双重挑战。在以制 度创新引领体制转型升级前提下, 根据中国沿海 11 个省市区的不同资源禀赋, 调整产业结构, 优化区域布局, 走特 色差异化创新发展之路是提高海洋渔业经济效率的可选路径。
\end{abstract}

关键词: 海洋渔业经济效率; 非期望产出; SBM; Kernel 密度; Tobit模型

DOI : $10.18402 /$ resci.2017.11.03

\section{1 引言}

21 世纪以来, 随着世界进入海洋世纪, 开发和 利用海洋资源日益成为世界各国海洋战略的重要 内容, 海洋渔业作为海洋资源的重要组成部分, 发 挥着越来越重要的作用。渔业经济对海洋经济的 贡献度逐年增加, 截止 2016 年, 海洋渔业占海洋产 业增加值的比重达到了 $16.2 \%$ 足。随着海洋渔业资 源的过度开发, 渔业资源枯竭成为全世界, 特别是 沿海国家和地区共同面临的问题。孙康等实证了 中国海洋渔业资源可持续利用呈现不可持续性 ${ }^{[2]}$ 。
中国作为海洋大国和渔业大国,面对这一世界难 题, 急切需要转型升级渔业产业结构, 提高渔业经 济效率, 充分发挥渔业资源的潜力。另一方面, 海 洋渔业资源的大规模开发, 提高了渔业经济效益等 期望产出, 同时也带来了污染等非期望产出, 导致 中国海域污染日益加剧, 海水环境严重恶化, 对海 洋渔业相关产业造成较大负面影响。鉴于中国渔 业资源枯竭,海域污染严重等现状,本文基于非期 望产出对中国海洋渔业经济效率进行测度和分析, 以期为中国海洋渔业产业结构转型升级和提高海

收稿日期: 2017-02-10 ; 修订日期: 2017-10-05

基金项目: 教育部人文社会科学重点研究基地重大课题(16JJD790021); 辽宁省社会科学规划基金项目(L16BJY041);国家自然科学基金 项目(41671119)。

作者简介: 孙康, 女, 辽宁本溪人, 博士, 教授, 硕士生导师, 研究方向为技术经济与渔业经济。E-mail : sunkangdl@163.com 通讯作者:李丽丹,E-mail : lilidan0615@163.com 
洋渔业经济效率提供科学支撑。

现有文献主要从以下三个角度对渔业经济效 率进行研究: (1)在渔业经济投人产出效率评价方 面, 肖姗等运用DEA方法对沿海省市海洋渔业经济 发展水平进行评价 ${ }^{[3]}$ 。梁盼盼等采用面板回归和 DEA 方法证实了1999-2010年间全国渔业全要素 生产率年均值未得到改善,存在技术进步但技术效 率降低、地区差异性明显的问题 ${ }^{[4]}$ 。(2)在技术生产 要素对渔业经济效率的影响方面,于淑华等运用基 于 DEA 的 Malmquist 指数方法测算中国沿海省市 区渔业产业效率和分省市区的全要素生产率,证实 了中国沿海多数省市区渔业产业效率仍表现为粗 放型的技术进步特征 ${ }^{\left[{ }^{[}\right]}$。杨卫等运用 DEA 模型分 析中国渔业科技生产效率,论证了中国渔业在技术 创新进程中存在的高投人问题,渔业纯科技效率未 达到规模有效水平 ${ }^{[0]}$ 。(3)在考虑资源环境影响下的 渔业经济发展方面,徐璐等研究中国环境约束下的 海洋渔业绿色增长的水平及地区收玫情况,证实中 国海洋渔业经济属于粗放型经济形式,大部分省市 动态海洋渔业绿色全要素生产率的增长率远低于 海洋渔业 GDP 增长率 ${ }^{[7]}$ 。GAO Jian 等基于资源的 稀缺性理论,证实了中国近海渔场和海洋渔业资源 不断减少,渔业生产要素经济效率下降的状况,成 为制约中国海洋渔业可持续发展的主要因素 ${ }^{[8]}$ 。

针对海洋渔业经济效率评价, 现有文献多基于 传统的 DEA 模型从海洋渔业经济投人产出绩效评 价或渔业经济发展水平等角度加以研究,主要关注 生产要素和期望产出 (一般是渔业经济总产值)的 效率关系,鲜有将渔业产业带来的非期望产出纳人 模型予以效率计算。值得关注的是渔业及其相关 产业带来的海域环境污染日益加剧, 对渔业经济效 益造成严重折损。因此,在衡量渔业经济效率时考 虑污染等非期望产出更具客观性及科学性。本文 构建了考虑非期望产出的 DEA-SBM 模型, 对中国 沿海 11个省市区 2004-2015 年海洋渔业经济效率 进行测度,刻画其时空格局演变过程。在分析各地 区时空格局分布特征的基础上,进一步利用 Tobit模 型回归探讨影响海洋渔业经济效率的影响因素, 以 期为提高中国海洋渔业经济效率, 实现海洋渔业经 济可持续发展提供参考。

\section{2 变量选取、数据来源与模型方法}

\section{1 变量选取与数据来源}

使用数据包络分析 (Data Envelopment Analysis, DEA) 方法测量效率结果的准确与否在很 大程度上依赖于测评过程中所使用的投人和产出 指标 ${ }^{[9]}$ 。投人指标方面, 根据西方经济学观点, 土 地、劳动力和资本通常是最基本的生产要素 ${ }^{[10]}$ 。在 海洋渔业经济投入指标方面,海洋渔业经济发展对 资源禀赋和海域环境的依赖性较强, 因此海洋资源 与环境的投人对海洋渔业的发展至关重要。借鉴 已有研究成果 ${ }^{[11-13]}$, 考虑到当前中国海洋渔业产业 结构中传统渔业仍占较大比重, 本文将沿海 11 省市 区 (不含港、澳、台地区) 作为决策单元, 将海水养殖 面积、渔船年末拥有量和海洋渔业劳动力作为投人 变量。产出指标方面,选取海洋渔业总产值作为期 望产出。在海洋渔业活动中, 不仅会产生期望产 出, 同时会产生废水、废物等非期望产出, 对海洋渔 业产值造成一定损失。基于《中国渔业生态环境状 况公报》 ${ }^{[14]}$ 对海洋天然渔业资源经济损失的估算原 则,依据该公报中污染对天然渔业经济损失的估算 方法, 具体测算出 2004-2015 年中国沿海 11省市 区的天然渔业经济非期望产出值,作为非期望产出 的量化指标 (鉴于海水养殖的非期望产出的难以测 度性,本研究尚未包括该部分的经济损失,因此理 论上中国海洋渔业经济效率值将低于本研究的结 果)。投人变量和期望产出变量的数据来源于《中 国渔业统计年鉴 $\rangle^{[15]}$,海洋渔业产值以 2000 年为基 期换算求得。海洋渔业经济效率量化评价指标体 系见表 1 。

\section{2 非期望产出的 SBM 模型}

在测度决策单元的效率方面,数据包络分析 (DEA) 已被证明是一种相当有效的工具 ${ }^{[16]}$ 。传统 DEA 方法应用主要集中于 CCR (A. Charnes \& W. W. Cooper \& E. Rhodes) 、BBC (Banker \& A.Charnes $\&$ W. W. Cooper)等径向的或者角度的模型,这些模 型的产出多基于期望产出,没有充分考虑投人、产 出的圥余和松弛性问题,也未能准确度量存在非期 望产出时的效率值 ${ }^{[17]}$ 。

Tone 提出了一个基于松弛测度的 SBM ( Slacksbased Measure) 模型处理非期望产出 ${ }^{[18]}$ 。假定 $n$ 个 
表 1 海洋渔业经济效率量化评价指标体系

Table 1 The index system of marine fishery economic efficiency

\begin{tabular}{clll}
\hline 目标层 & 基准层 & & 指标层 \\
\hline 海洋 & 投人指标 & 自然资源投人 & 海水养殖面积 $/ \mathrm{hm}^{2}$ \\
渔业 & & 资本投人 & 渔船年末拥有量 $/ \mathrm{t}$ \\
经济 & & 劳动力投人 & 海洋渔业劳动力 $/ 人$ \\
效率 & 期望产出指标 & 经济产出 & 海洋渔业总产值 $/$ 万元 \\
& 非期望产出指标 & 天然海洋渔业负效应 & 海洋天然渔业损失(海洋渔业水域污染估算值)/t \\
\hline
\end{tabular}

注:用海水养殖面积作为自然资源投人的替代指标,原因在于海水养殖面积是能够获得的代替近海海域面积 的最佳指标,其它能够代替自然资源投入的替代指标都没有具体到省际层面。

独立的决策单元( Decision Making Unit, DMU), 表 示成 $D M U_{j}(j=1,2, \cdots, n)$ 。 $x$ 和 $y$ 分别为输人和输出 变量, $m$ 和 $r$ 分别为输人和输出变量的个数。每个 决策单元消耗 $m$ 个投人 $X_{i j}(i=1,2, \cdots, m)$,生产 $S_{1}$ 个 期望产出 $Y^{g}$ 和 $S_{2}$ 个非期望产出 $U^{b}$, 则投人、期望 产出和非期望产出 3 个向量分别用 $x \in R^{m}$, $y^{g} \in R^{S_{1}}, u^{b} \in R^{S_{2}}$ 表示, 定义矩阵 $\boldsymbol{X} 、 \boldsymbol{Y}^{g} 、 \boldsymbol{U}^{b}$ 分别如下:

$$
\begin{aligned}
& X=\left[x_{1}, \cdots, x_{n}\right] \in R^{m \times n} \\
& \boldsymbol{Y}^{g}=\left[y_{1}^{g}, \cdots, y_{n}^{g}\right] \in R^{S_{1} \times n} \\
& \boldsymbol{U}^{b}=\left[u_{1}^{b}, \cdots, u_{n}^{b}\right] \in R^{S_{2} \times n} \\
& \text { 且 } X>0, Y^{g}>0, U^{b}>0 \text { 。其生产可能集 } P \text { 定义 }
\end{aligned}
$$
如下:

$P=\left\{\left(x, y^{g}, u^{b},\right) \mid x \geqslant X \lambda, y^{g} \leqslant Y^{b} \lambda, u^{b} \geqslant U^{b} \lambda, \lambda \geqslant 0\right\} 。$

本文采用 Tone 提出的考虑非期望产出的 SBM 模型 ${ }^{[19]}$, 可表示为:

$$
\begin{gathered}
p=\min \frac{1-\frac{1}{m} \sum_{i=1}^{m} \frac{s_{i}^{-}}{x_{i 0}}}{1+\frac{1}{s_{1}+s_{2}}\left[\sum_{r=1}^{s_{1}} \frac{s_{r}^{g}}{y_{r 0}^{g}}+\sum_{r=1}^{s_{2}} \frac{s_{r}^{b}}{u_{r 0}^{b}}\right]} \\
\text { s.t. }\left\{\begin{array}{l}
x_{0}=X \lambda+s^{-} \\
y_{0}^{g}=Y^{g} \lambda-s^{g} \\
y_{0}^{b}=Y^{b} \lambda-s^{b} \\
s^{-} \geqslant 0, s^{g} \geqslant 0, s^{b} \geqslant 0, \lambda \geqslant 0
\end{array}\right.
\end{gathered}
$$

式中 $s=\left(s^{-}, s^{g}, s^{b}\right)$ 分别代表投人、期望产出和非期望 产出的松弛变量; $\lambda$ 为权重向量; $p$ 为目标函数,关 于 $s^{-}, s^{g}, s^{b}$ 是严格递减的, 且 $0 \leqslant p \leqslant 1$ 。对于每一 个被评价的决策单元, 当且仅当 $p=1$, 即 $s^{-}=0$, $s^{g}=0, s^{b}=0$ 时,被评价的决策单元才是有效率的; 若 $p<1$, 则说明被评价的决策单元是无效率的,在
投人和产出方面还存在一定的改进空间 ${ }^{[20]}$ 。为了便 于分类分析, 参考马占新的研究 ${ }^{[2]}$, 设定效率值 $p=1$ 为效率最高; $0.8 \leqslant p<1$ 为效率良好; $0.6 \leqslant p<0.8$ 为效率中等; $p<0.6$ 为效率无效。

\subsection{Tobit 模型}

Tobit模型也被称为样本选择模型, 是被解释变 量在满足某种约束条件取值的模型。Tobit 回归模 型可写为:

$$
Y= \begin{cases}Y^{*}=\alpha+\beta X+\varepsilon, & Y^{*}>0 \\ 0 & Y^{*} \leqslant 0\end{cases}
$$

式中 $Y$ 为截断的被解释变量; $X$ 为解释变量; $\alpha$ 为 截距项; $\beta$ 为回归参数; $\varepsilon$ 为扰动项且 $\varepsilon \sim N\left(0, \sigma^{2}\right)$ 。 在 Tobit 回归模型中, 效率值作为被解释变量属于截 断的离散分布数据。当被解释变量是部分连续分 布或者部分离散分布数据时,采用普通最小二乘法 (OLS)进行估计存在一定偏误, 需利用最大似然法 (MLE) 对 Tobit模型中的参数进行估计。

\section{3 海洋渔业经济效率SBM 模型分析}

根据上述模型,运用MaxDEA6.4 软件,估算沿 海 11省市区 2004-2015 年考虑非期望产出 (SBM 模型)的海洋渔业经济效率值(表 2)。结果显示, 在 研究期内海洋渔业经济效率整体处于较低水平。

\section{1 海洋渔业经济效率对比分析}

根据各地区海洋渔业经济效率的演化特征,在 研究期内, 全国显示出均匀波动且有小幅上扬的趋 势。分类型来看, 可以将沿海 11 省市区划分为高效 稳定型、中效稳定型、低效稳定型和中效波动型 4 种 类型。高效稳定型地区包括天津、上海、江苏、海 南,在研究期内效率值始终维持在 1 且保持不变; 中 效稳定型地区包括浙江与福建,渔业经济效率始终 
表 2 基于考虑非期望产出的 SBM 模型 2004-2015 年海洋渔业经济效率值

Table 2 The marine fishery economic efficiency value based on SBM model with undesirable output from 2004 to 2015

\begin{tabular}{cccccccccccccccccc}
\hline 年份 & 2004 & 2005 & 2006 & 2007 & 2008 & 2009 & 2010 & 2011 & 2012 & 2013 & 2014 & 2015 \\
\hline 天津 & 1.000 & 1.000 & 1.000 & 1.000 & 1.000 & 1.000 & 1.000 & 1.000 & 1.000 & 1.000 & 1.000 & 1.000 \\
河北 & 0.252 & 0.264 & 0.241 & 0.155 & 0.152 & 0.136 & 0.161 & 0.158 & 0.207 & 0.352 & 0.366 & 0.322 \\
辽宁 & 0.315 & 0.365 & 0.385 & 0.352 & 0.322 & 0.256 & 0.268 & 0.228 & 0.241 & 0.184 & 0.219 & 0.254 \\
上海 & 1.000 & 1.000 & 1.000 & 1.000 & 1.000 & 1.000 & 1.000 & 1.000 & 1.000 & 1.000 & 1.000 & 1.000 \\
江苏 & 1.000 & 1.000 & 1.000 & 1.000 & 1.000 & 1.000 & 1.000 & 1.000 & 1.000 & 1.000 & 1.000 & 1.000 \\
浙江 & 0.727 & 0.850 & 0.935 & 0.930 & 0.922 & 0.856 & 0.838 & 0.867 & 0.848 & 0.814 & 0.872 & 0.896 \\
福建 & 1.000 & 1.000 & 0.985 & 0.945 & 1.000 & 0.916 & 0.967 & 0.962 & 0.979 & 0.912 & 0.875 & 0.861 \\
山东 & 0.555 & 1.000 & 1.000 & 0.678 & 0.536 & 0.516 & 1.000 & 0.499 & 1.000 & 1.000 & 1.000 & 1.000 \\
广东 & 0.406 & 0.633 & 0.762 & 0.673 & 0.713 & 0.752 & 0.836 & 0.702 & 0.703 & 0.408 & 0.473 & 0.561 \\
广西 & 0.330 & 0.335 & 0.290 & 0.253 & 0.369 & 0.344 & 0.361 & 0.316 & 0.397 & 0.342 & 0.287 & 0.526 \\
海南 & 1.000 & 1.000 & 1.000 & 1.000 & 1.000 & 1.000 & 1.000 & 1.000 & 1.000 & 1.000 & 1.000 & 1.000 \\
几何平均值 & 0.609 & 0.692 & 0.697 & 0.623 & 0.631 & 0.600 & 0.661 & 0.595 & 0.667 & 0.634 & 0.647 & 0.696 \\
\hline
\end{tabular}

维持在中高效率, 效率值始终在 0.1 0.21 之间波 动。其中福建缓中有升但不明显, 浙江略有上升但 不显著;低效稳定型地区包括辽宁、河北、广西,样 本期内效率始终处于无效率状态, 效率值低于全国 平均水平。其中河北在 2012 年前效率在波动中下 降,2012年后呈现明显上升趋势。辽宁整体波动不 明显但略有下降。广西在 2015 年有明显的上升但

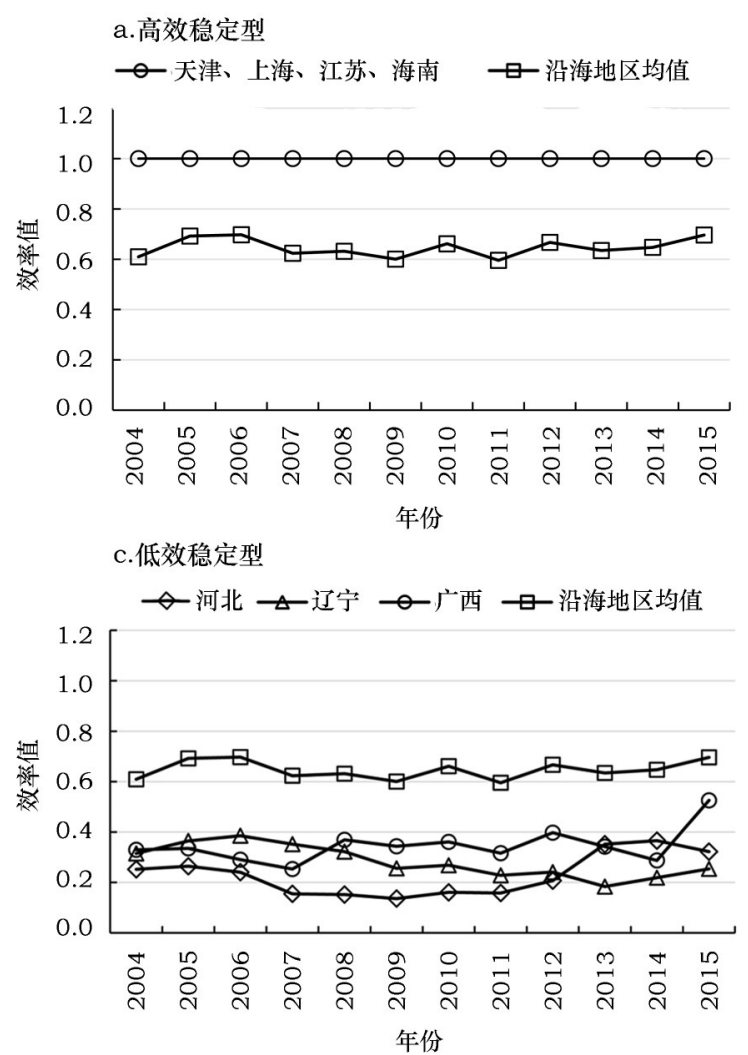

仍处无效状态 ; 中效波动型地区包括山东与广东, 渔业经济效率波动明显。样本期内山东效率值呈 现出先上升再下降再上升并剧烈波动的显著变化 趋势。广东在 2010 年之前效率值呈现上升的趋势, 2010 年后下降趋势明显并在 2012 年出现剧烈下 降,2012年后触底反弹又缓慢上升。

(1)高效稳定型地区(图 1a)。包括天津、上海、 b.中效稳定型

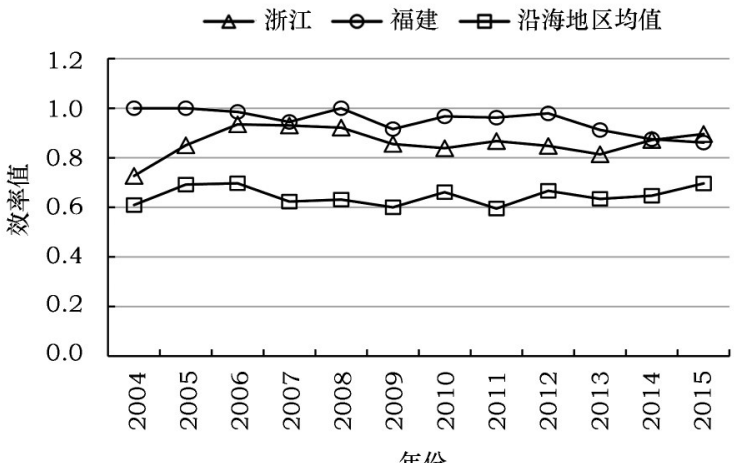

d.中效波动型

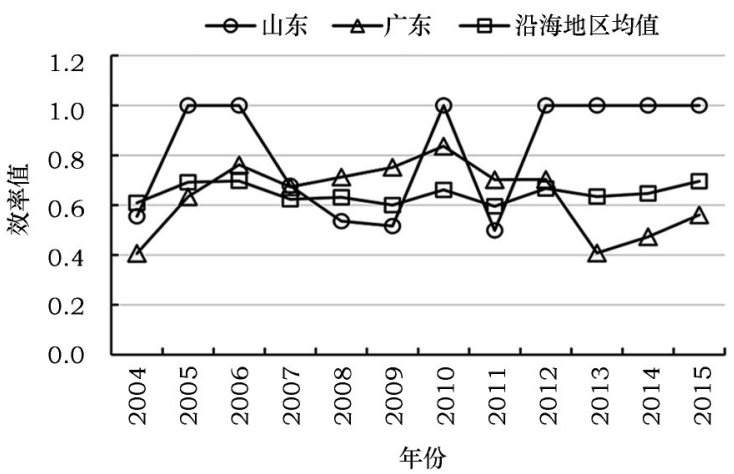

图 12003 - 2014年沿海 11 省市区海洋渔业经济效率值

Figure 1 The marine fishery economic efficiency values for 11 coastal provinces from 2003 to 2014 
江苏和海南。天津、上海、江苏属于沿海经济发展 水平较高地区, 海洋各个产业发展较好, 渔业经济 结构合理。高水平的渔业科技投人,提升了海洋渔 业劳动生产率, 降低了单位产值的资源消耗。三省 市渔业产业集聚化水平较高,渔业第三产业发展较 快, 总体上渔业经济效率持续稳定地处在高水平区 间。海南较高的效率得益于优质的近海水环境,近 海海水质量直接影响到海洋天然渔业损失量。同 时海南渔业第三产业发展较好,地区经济与生态环 境的协调高,故其保持在高水平范围。

(2)中效稳定型地区 (图 1b)。浙江与福建都是 传统的渔业大省,两省的渔业资源丰富,渔业产业 集聚水平高。两省的海洋经济基础雄厚,对外开放 水平较高,同时科技研发力度大。福建通过较早的 享受国家的优惠政策及地方政府对渔业经济灵活 的政策调整。促进了渔业经济的发展,使渔业产业 始终处于较高水平波动; 浙江在传统渔业优势基础 上,通过政府出台一系列治理水污染的政策,结合 科技手段,使渔业经济的非期望产出降低,并调整 渔业经济结构,使渔业经济结构日趋合理,让处于 高水平的渔业经济效率进一步上升。

（3）低效稳定型地区(图 1c)。包括河北、辽宁 和广西。辽宁与河北两省同处环渤海地区, 水域污 染严重导致非期望产出过多。渤海地区,地理因素 的特殊性导致渤海的自我修复能力较弱, 自我修复 时间较长,工业与生活污水的过度排放导致水域污 染严重。辽宁为传统的渔业大省,渔业经济结构调 整受限于地方经济发展停滞不前,地方政府渔业科 研力度投人不足,严重阻碍了渔业劳动生产率的提 升。渔业产业集聚不仅没有促进产业升级，反而导 致渤海过度捕捞,造成“公地悲剧”。渔业资源退 化, 渔业人口拥挤产出过少, 导致渔业生产效率低 下,降低了渔业经济效率。河北资源要素禀赋不足 制约了海洋渔业经济发展。广西经济相对落后, 渔 业经济以第一产业为主, 劳动生产率相对较低, 拉 低了本地区的渔业经济效率。

(4) 中效波动型地区 (图 1d)。山东与广东两省 都是传统渔业大省, 二省经济实力雄厚,政府财政 支出占地区 GDP 的比重相对较高, 基于现有文献中 对地方政府行政能力的评价,认为两地区地方政府
行政能力较强。山东发达的陆域经济显著促进海 洋渔业经济, 渔业技术水平高, 渔业劳动生产率较 高。但地处黄海与渤海地区, 渔业水域污染严重, 渔业非期望产出较大, 导致山东渔业经济效率先上 升再下降。“十一五”期间中央政府为全面治理水域 污染, 设立了水污染情况直接与官员晋升挂钩的行 政政策 ${ }^{[22]}$,地方政府官员对水环境治理高度关注。 山东省政府出台一系列治理水域污染的地方性法 规 ${ }^{[23]}$ 。渔业水域污染减少,非期望产出降低,渔业经 济效率提高,但 2011 年蓬莱 19-3 油田溢油事故直 接导致本省渔业部分水域污染恶化 ${ }^{[24]}$, 非期望产出 增多,渔业经济效率降低。总体上山东省内的环境 规制是有效的。广东的渔业发展较快,渔业规模较 大,渔业产业较高但海域污染程度相对较高, 非期 望产出也较大, 故广东渔业产出起始值较低。因广 东经济基础雄厚,科研能力较高, 政府通过加大对 渔业的投人逐渐使得广东渔业经济效率上升随着 渔业产业的集聚,渔业资源个体小型化、低龄化和 低质化趋势使得渔业总产值下降,进而影响到了渔 业经济效率, 广东于 2011 年进行海洋功能区划 ${ }^{[25]}$, 强调将生态环境修复放在首位,渔业劳动生产率下 降,使得渔业经济效率总体出现下滑趋势。2014年 后通过加大科技投人、增殖放流、设立人工鱼礁、减 少污水排放等措施 ${ }^{[25]}$, 使渔业劳动生产率提高、渔业 水域污染降低,渔业经济效率有所改善。

\section{2 时间序列演化分析}

中国海洋渔业经济效率时间演化态势分析。 应用 Eviews8.0 对表 1 海洋渔业经济效率值进行 Kernel密度(下称核密度)估计,得出核密度分布图 （图 2）。其中选取了更具代表性的首末年份 2004 年、2015 年以及中间年份 2009 年的效率值绘制了 核密度曲线,通过不同时期的比较,得出中国海洋 渔业经济效率动态演变特征。

(1) 从位置上看, 考虑非期望产出的核密度分 布所选 3 个年份的密度函数中心, 整体呈现向右移 动态势。其中 2009 年相比 2004 年有较大幅度左 移, 2015 年相较 2009 年与 2004 年右移显著, 说明 2004-2009年前后中国海洋渔业经济效率略微下 降,2009年以后经过政府政策调整及治理 ${ }^{[14]}$ 中国海 洋环境得到一定改善,海洋渔业经济效率出现好转 


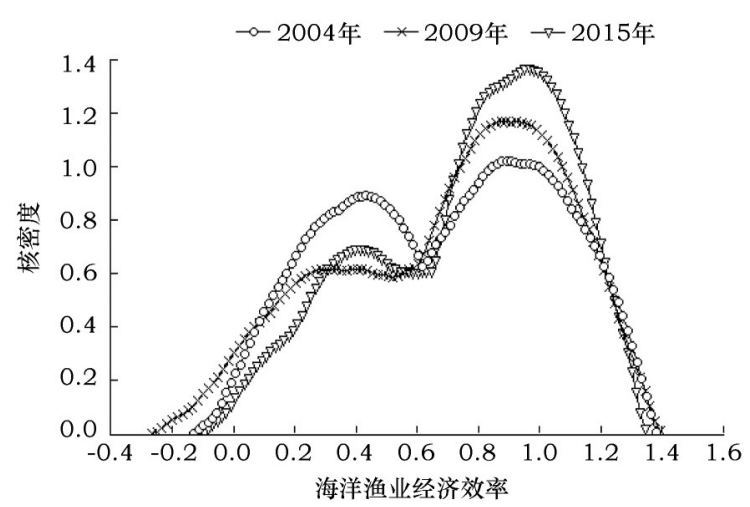

图 2 海洋渔业经济效率 Kernel 密度分布

Figure 2 The kernel density distribution of marine fishery economic efficiency

趋势。

(2) 从形状上看,三个样本区间的核密度将 11 个省市区海洋渔业经济效率客观地划分为低效率 区与高效率区, 且高效率与低效率出现明显的分水 岭。2009年及 2015 年渔业经济效率分布坡度均较 为陡峭,高密度出现在效率值较高的区域;2004 年 效率分布坡度较为和缓、密度降低。从三个样本区 间的非期望产出的核密度分布比较来看, 效率值分 布双峰起伏逐渐加大, 表明中国海洋渔业经济效率 两极分化态势逐渐增强。

(3) 从峰值上看, 三个样本区间的非期望产出
核密度变化,表现为 2004-2009年海洋渔业经济效 率由宽峰演变为尖峰, 且峰值呈现出低效率地区明 显下降高效率地区略微上升的趋势, 说明研究样本 区间海洋渔业经济效率波动明显呈现两极分化态 势。2004年及 2015 年海洋渔业经济效率呈明显的 双峰分布, 低效率水平的峰值低于高效率水平的峰 值, 不同样本区间峰值间垂直距离加大。说明总体 上海洋渔业经济效率得到一定改进,低效率地区数 量少于高效率地区,但两极分化态势没有得到有效 改善。

\section{3 时空差异分析}

基于考虑非期望产出的 SBM 模型, 以 2004 2015 年中国沿海 11 省市区海洋渔业经济效率值为 基础,选取 2004 年、2009年和 2015 年的截面数据, 运用 ArcGIS10.0 对各沿海省市区海洋渔业经济效 率进行时空分析,绘制出时空格局演化分布图 3。

3.3.1 各沿海省市区海洋渔业经济效率时空特征

由图 3 可知,在三个样本期间内的 2004 年, 天 津、上海、江苏、海南和福建的渔业经济效率值为 1 , 在沿海省市中排名最高; 排名第三的仅有浙江一个 省份效率值较高,渔业经济效率良好; 剩下的省市 区排名第四也是排在最后效率值最低, 且与高效率 值地区差距较大,处低效率区间。2009年,总体上 高效率省市区数量略有上升, 排在第二名的天津、

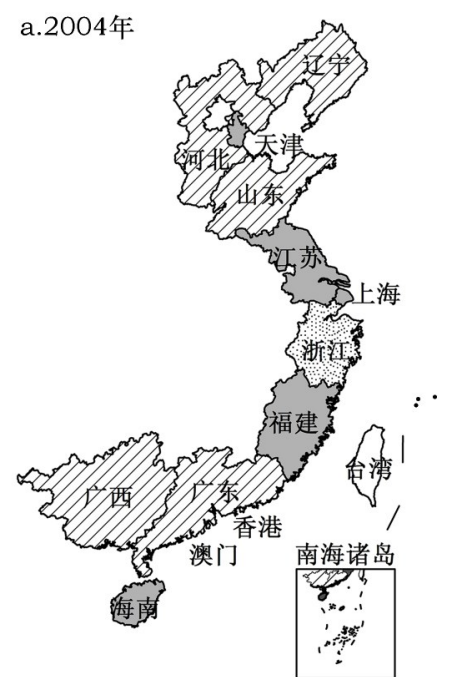

海洋渔业经济效率

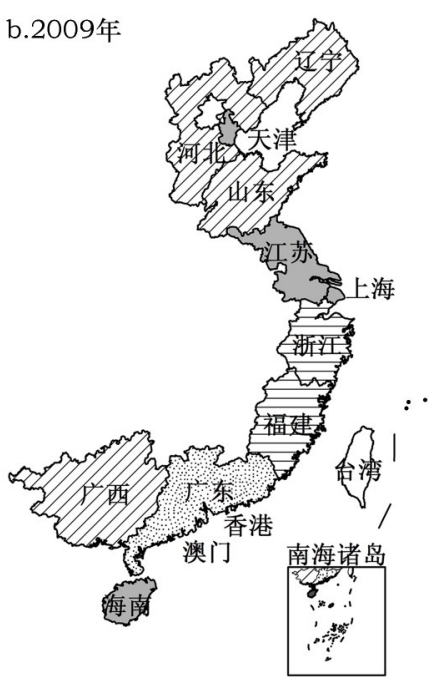

$1.0 \square$ 无数据

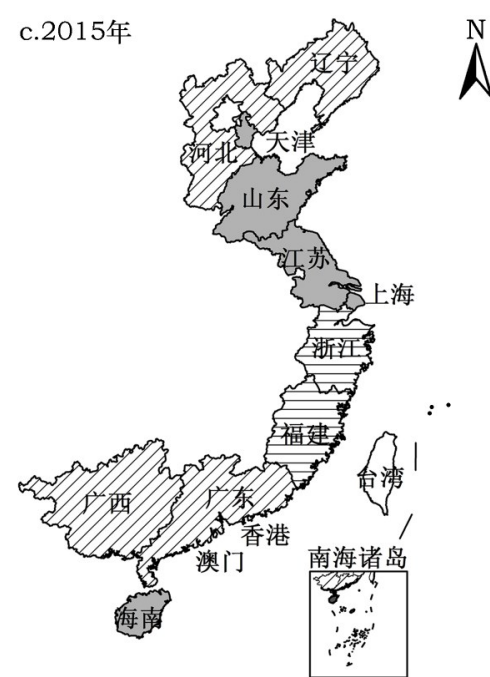

$0 \quad 500 \quad 1000 \mathrm{~km}$

图 3 考虑非期望产出的海洋渔业经济效率空间格局演化 (香港、澳门、台湾无数据)

Figure 3 The spatial evolution of marine fishery economic efficiency with considering undesirable outputs 
上海、江苏和海南依然属于效率值最高区域,期间 浙江、福建效率值上升至排名第一的高效率地区; 广东上升至排名第三的中等效率地区; 排在第四名 的辽宁、河北、山东、广西效率值不但没有改进,并 且同高效率地区效率值差距拉大。2015 年,排名最 高效率省市区的数量增加一个,除了天津、上海、江 苏和海南四省市效率值均为 1 处于最高效率水平区 域之外, 山东效率水平提高, 效率值上升至 1 , 进人 排名第一的最高效率水平行列; 浙江、福建排名第 二未变,仍处高效率水平区域;广东效率水平从排 名第三降低至第四,效率值降低,与辽宁、河北、广 西同处低效率值区间,且效率值水平地区间差距拉 大。从三个样本区间比较来看, 总体而言, 各省市 区历年海洋渔业经济效率值在空间上并没有较大 跨度但略有变化,效率排名第一的地区 (如天津、上 海、江苏和海南)基本上一直保持较高的效率水平 未有变化; 效率值最低的地区 (如河北、辽宁)一直 处最低效率水平; 其余省份历年效率值略有波动但 未发生显著变化,其中变化最大的是山东, 从排名 最后跃升到第一。总体而言, 效率值排名第一的省 市区数量上和面积上基本未变; 效率值排名第四的 省市区数量上和面积上也基本未变; 效率值排在中 间的省市区有所波动。从三个样本区间的空间演 化来看,两极分化态势没有改善。

\subsection{2 海洋渔业经济效率空间格局划分}

依据各省市区海洋渔业经济效率历年变化特 点,将沿海 11 省市区划分为 4 种类型。

(1) 高效稳定型。天津、上海、江苏和海南,一 直处于最高水平并保持稳定, 各年渔业经济效率值 均为 1 , 为完全有效地区。前三者主要得益地区陆 域经济发达,技术水平较高, 主要依靠科技含量较 高的渔业二、三产业带来较高的渔业经济产出,传 统渔业占比较小,污染对其渔业第一产业造成的经 济损失较少,从而保持较高的渔业经济效率。海南 渔业规模相对较小,但海域环境良好,由污染所造 成的非期望产出较少,具有较明显优势, 从而达到 高效率水平。

(2)中效稳定型。浙江和福建部分年份处高效 率水平区, 同时处于波动状态, 样本期内有少许年 份效率值下降为效率良好水平或低效率水平,此类
地区具有达到完全有效的高效率值的较大潜力。 浙江与福建渔业规模大、经济基础好,传统渔业占 比与低效率地区相比适中, 具有一定提升空间。

（3）低效稳定型。河北、辽宁和广西省历年渔 业经济效率值均处于较低水平且保持相对稳定,一 直未出现显著提升。其中, 河北与中等水平波动型 地区相较,渔业规模较小,但海域污染状况较为严 重, 从而渔业经济效率值较低,加之河北经济发展 水平有限,科技水平一般,致使渔业经济效率未得 到有效改善。辽宁虽然是渔业大省,渔业规模较 大, 但渔业产业结构中传统渔业占比较高, 仍主要 依赖渔业第一产业带来渔业经济产出, 且海域污染 程度较高, 污染造成的经济损失也较大, 很大程度 上降低了其渔业经济效率。广西经济发展相对滞 后,渔业产业结构落后,传统渔业经济占主导, 渔业 经济效率相对较低。

(4)中效波动型。山东、广东渔业经济效率值 总体属于效率中等水平,历年的效率值有大幅度的 波动。此类地区的特点是渔业规模较大,渔业经济 产出较高, 但海域污染程度较高, 由污染造成的渔 业经济损失也较多,对渔业经济产出有相当程度的 折损,从而降低了渔业经济效率。

综合时间序列分析与时空差异分析来看,中国 海洋渔业经济效率几何平均值维持在 0.6 左右, 显 示出中国海洋渔业经济效率整体偏低; 高效地区由 期初的 6 个上升为期末的 7 个,低效地区由期初的 5 个下降为期末的 4 个,总体上显示中国沿海 11 省市 区海洋渔业经济发展所呈现的两极分化态势未得 到明显改进。

\section{4 海洋渔业经济效率影响因素分析}

为了进一步分析海洋渔业经济效率的影响因 素, 将渔业经济效率作为因变量, 各影响因素作为 自变量,建立面板回归模型对可能影响海洋渔业经 济效率的因素进行回归分析。因变量为考虑非期 望产出的各地区历年海洋渔业经济效率值, 参考现 有文献 ${ }^{[26-28]}$ 并考虑数据的可获得性, 解释变量选取 人均海洋渔业经济总产值 $\left(X_{1}\right)$ 、海洋渔业二、三产业 所占比重 $\left(X_{2}\right)$ 、海洋渔业资源利用率 $\left(X_{3}\right)$ 、海洋渔业 比较劳动生产率 $\left(X_{4}\right)$ 、海洋渔业科研机构密度 $\left(X_{5}\right)$ 和海洋渔业就业专业化指数 $\left(X_{6}\right)$ 等 6 个指标(表 3$)$,分别 


\section{表 3 解释变量计算方法}

Table 3 Calculation methods of explanatory variable

\begin{tabular}{cll}
\hline $\begin{array}{c}\text { 解释 } \\
\text { 变量 }\end{array}$ & \multicolumn{1}{c}{ 名称 } & \multicolumn{1}{c}{ 计算方法 } \\
\hline$X_{1}$ & 人均海洋渔业经济总产值 & 海洋渔业总产值/海洋渔业人 \\
& & 口 \\
$X_{2}$ & 海洋渔业二、三产业比重 & 海洋渔业二、三产业增加值/ \\
& & 海洋渔业总产值增加值 $\times 100$ \\
$X_{3}$ & 海洋渔业资源利用率 & 海洋渔业产值/海域面积 \\
$X_{4}$ & 海洋渔业比较劳动生产率 & 地区海洋渔业产值比重/地区 \\
& & 海洋渔业劳动力比重 $\times 100$ \\
$X_{5}$ & 渔业科研机构密度 & 地区渔业科研机构数/全国渔 \\
& & 业科研机构总数 $\times 100$ \\
$X_{6}$ & 海洋渔业就业专业化指数 & 地区海洋渔业专业从业人员/ \\
& & 海洋渔业从业人员总数 $\times 100$ \\
\hline
\end{tabular}

代表海洋渔业经济发展水平、海洋渔业产业结构优 化水平、海洋渔业可持续发展水平、海洋渔业劳动 生产力水平、科研支持力度及渔民从业专业化水 平。上述各指标数据来源于 2005-2016年的《中国 渔业统计年鉴》 ${ }^{[15]}$ 和《中国海洋统计年鉴》| ${ }^{[29]}$ 。

由于 DEA方法计算出的效率值大都介于 0 和 1 之间,故因变量的数值面临切割或截断问题,如果 采用普通最小二乘法 $(\mathrm{OLS})$ 来估计无法完整地呈 现数据, 将导致估计偏差 ${ }^{[30]}$ 。基于此,本文选用遵循 最大似然法概念的面板 Tobit 模型来进行回归分 析 ${ }^{[31]}$, 结合各影响因素指标及数据的特征, 选取年 份变量作为时间随机效应, 建立模型如下:

$$
\begin{aligned}
Y_{i t}= & \beta_{0}+\beta_{1} X_{1}+\beta_{2} X_{2}+\beta_{3} X_{3}+\beta_{4} X_{4}+\beta_{5} X_{5} \\
& +\beta_{6} X_{6}+\delta+\varepsilon
\end{aligned}
$$

式中 $Y_{i t}$ 为第 $i$ 个省市在第 $t$ 年的基于非期望产出海 洋渔业经济效率值; $\beta_{0}, \beta_{1}, \beta_{2}, \cdots, \beta_{6}$, 为各解释 变量的回归系数; $\delta$ 为时间随机效应; $\varepsilon$ 为回归的 误差项。选用 Stata13.0 软件对上述影响海洋渔业 经济效率的因素进行回归分析,具体结果见表4。

由表 4 的回归结果可知:

(1)海洋渔业经济发展水平、劳动生产力水平、 科研支持力度对海洋渔业经济效率具有正向作 用。用人均海洋渔业经济总产值衡量地区海洋渔 业经济发展水平。一般而言,地区海洋渔业经济发 展水平越高, 发展时间越长, 相应的资金、技术和基 础设施等愈加完善,为提高海洋渔业经济效率奠定

\section{表 4 沿海各省市区海洋渔业经济效率影响因素回归结果}

Table 4 Regression results of influence factors about marine fishery economy efficiency for coastal provinces

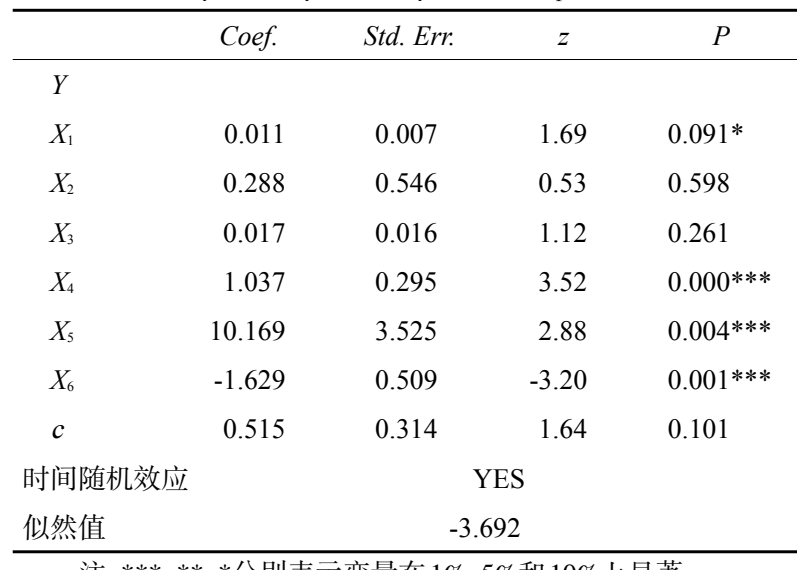

注: ***、**、分别表示变量在 $1 \%$ 、5\%和 $10 \%$ 上显著。

良好基础; 另一方面,较高的海洋渔业经济发展水 平带动了地区人均海洋渔业经济总产值的提升,渔 民的劳动价值在增加,激发了渔民从事海洋渔业劳 动的积极性, 为海洋渔业可持续发展提供了有利支 撑。因此,海洋渔业经济发展水平与渔业经济效率 是相互促进的正向变化关系。用于衡量劳动生产 力水平的海洋渔业比较劳动生产率由地区海洋渔 业产值比重除以地区海洋渔业劳动力比重计算所 得,其大小代表单位劳动力可以创造的渔业产值的 高低,海洋渔业比较劳动生产率越高, 说明单位劳 动力可以创造更大的渔业经济效益, 从而对渔业经 济效率有正向促进作用。科研支持度代表了各地 区对渔业经济发展的重视程度,体现在地区科研机 构的数量以及政府等部门对科研机构的资金和政 策扶持力度, 科研支持度也直接影响本地区的渔业 科技能力, 该指标越大, 渔业科技水平越发达,单位 劳动力所产生的海洋渔业总产值越多, 渔业经济效 率就越高。

(2)海洋渔业就业专业化指数对海洋渔业经济 效率具有显著的负向作用。海洋渔业就业专业化 指数代表渔民从业专业化水平, 渔民从业专业化水 平理应与效率成正向关系。由于考虑了非期望产 出, 导致负向关系凸显。原因在于,一是专业化水 平越高, 过度捕捞强度越大, 加速了海洋渔业资源 的枯竭; 二是粗放式的转产转业政策的落实效果造 成一定的海域污染负效应。在渔业经济转型关键 
时期,政府期望通过转产转业提高渔民的专业素 质, 提升专业技术水平, 在渔业经济发展和转型中 发挥作用,在投资回报率更高的新型渔业产业中创 造较高的经济效益,进一步提高渔业经济效率。由 于政府在实施转产转业和环境保护等相关政策过 程中,存在信息不对称,造成我国目前的转产转业 政策形成一种粗放式的转移。渔民弃船后大多转 向了海水养殖业(渔业第一产业内部转移),致使海 洋渔业陷人高密度、超容量的“过度养殖”困境, 海 水养殖资源供需矛盾进一步加剧, 海洋渔业生态环 境日趋恶化 ${ }^{[32]}$ 。海洋资源的稀缺性造成目前这种粗 放式的渔业转产转业政策导致海洋生态环境进一 步恶化,海洋渔业经济效率降低。因此海洋渔业就 业专业化指数与海洋渔业经济发展出现负向关系。

(3)海洋渔业产业结构优化水平, 海洋渔业可 持续发展水平与海洋渔业经济效率无明显相关关 系。渔业产业可以分为渔业第一产业、渔业第二产 业和渔业第三产业,用渔业二、三产业所占比重来 衡量海洋渔业产业结构优化水平,其代表地区渔业 经济的发达程度。与传统的渔业第一产业相比,渔 业二、三产业对资源的依赖度较低,但技术含量和 投资回报率较高。以渔业第三产业中的休闲渔业 为例, 其将旅游业与渔业相结合, 摆脱了单纯对渔 业资源的过度依赖,使渔业相关的产业也能带来较 高的经济效益。由此,渔业二、三产业的发展规模 和发展程度对渔业经济效率有正向促进作用,但纵 观历年沿海各省份相关数据, 海洋渔业产业中, 传 统渔业仍然占有较大份额,海洋渔业二、三产业增 加值占海洋渔业总产值增加值的比重除个别可以 达到 40\% 50\%之外, 大部分省份都在 10\%左右, 即 海洋渔业二、三产业对渔业经济总产值的贡献度较 低，虽然对海洋渔业经济发展呈正向相关但不显 著; 海洋渔业可持续发展水平用渔业资源利用率表 示, 由海洋渔业产值除以海域面积计算得到,代表 单位海域面积创造的渔业经济效益。该指标在对 海水养殖、海洋捕捞等传统渔业依赖程度较大的省 份具有较为显著影响,对其他省份影响较小。以渔 业经济效率值较高的天津和上海为例，二者的海水 养殖面积在沿海 11 省市中数量最小, 处于最后两位 且明显低于其他省份, 2008 年后上海的海水养殖面
积降为零,但其渔业经济效率值却位于最前列。主 要原因是此类地区经济发达,技术水平较高, 重点 依靠科技含量较高的新型渔业产业带来较高的经 济收益, 对传统渔业的依赖度较低, 从而较少受到 资源禀赋的约束,用单位海域面积创造的渔业产值 衡量的渔业资源利用率对其渔业经济效率影响呈 正向相关但并不显著。

\section{5 结论}

本文采用考虑非期望产出的 SBM 模型, 测度沿 海 11省市区 2004-2015 年海洋渔业经济效率, 并 进行对比分析。考虑非期望产出的海洋渔业经济 效率值反映在海洋环境污染状态下海洋渔业经济 效率的变化具有一定的客观性,故本文选取水域环 境污染造成的海洋天然渔业资源经济损失作为非 期望产出的指标。运用Kernel密度及 GIS 空间技术 刻画考虑非期望产出情况下沿海各省市历年效率 值的时空格局变化。在此基础上,对影响海洋渔业 经济效率值的多种因素进行 Tobit 回归分析, 得出以 下结论：

(1)时间序列分析来看,沿海各省市区历年海 洋渔业经济效率值呈现不同程度的波动趋势, 且高 效率水平地区基本保持不变。考虑非期望产出,沿 海各省海洋渔业经济几何平均效率值维持在 0.6 左 右且随时间变化略有上扬, 总体效率水平一般, 说 明中国整体海洋渔业经济效率不高。

(2)空间差异分析来看,在研究期内,各个水平 的海洋渔业经济效率值空间分布较为稳定, 区域跨 度并不明显, 天津、上海、江苏和海南始终处于效率 值的最高水平, 河北、辽宁和广西一直处于效率值 最低水平,其余省份效率值有一定程度浮动但总体 变化不显著。

(3)时空差异分析来看,整体上中国海洋渔业 经济发展效率偏低, 反映出中国近年来的相关海洋 渔业经济规制效果不理想。从 11 个省市区角度来 看, 中国海洋渔业经济效率地区间差异明显,呈现 出不均衡特征,说明沿海 11 个省市区渔业经济发展 两极分化态势未得到有效改善。

(4)Tobit 回归结果表明,影响海洋渔业经济效 率的各个因素中, 科技水平的作用程度较为显著, 技术水平的提升是提高海洋渔业经济效率的关键 
因素之一, 是促进渔业产业结构转型升级的主要因 素。鉴于海洋渔业就业专业化指数与效率出现负 向关系,渔业转产转业政策需提质增效。渔业第一 产业(传统渔业)的影响因素对渔业经济效率值的 提升效果不明显,需进一步调整渔业产业结构中渔 业第一产业的比重。

基于上述海洋渔业经济效率的时空分布特征， 海洋渔业经济发展规模虽逐步增大,但仍然很大程 度上依赖渔业第一产业, 表明中国海洋渔业经济效 率规模不经济趋势明显。各地区渔业产业结构差 异较大, 导致海洋渔业经济效率水平差距加大, 两 极分化态势明显。进一步提升渔业二、三产业的比 重是调整渔业产业结构的重中之重。从提升渔业 经济效率角度看,渔业二、三产业科技含量更高, 对 资源禀赋依赖程度较小,更易得到较高的经济收益 和渔业经济效率值。未来继续注重科技水平发展， 加大科技投人, 提高渔业经济效率, 是促进渔业产 业转型升级、实现传统渔业向现代渔业转化的有效 途径。

由于海水养殖的非期望产出数据难以获得, 本 文仅考虑天然渔业环境水域污染所造成的非期望 产出。未来在获取数据手段成熟时,加人海水养殖 所造成的非期望产出后,实证分析结果将与现实情 况更加吻合, 对分析海洋渔业经济效率更具有客 观性。

\section{参考文献(References) :}

[1] 国家海洋局. 中国海洋经济统计公报 2004-2016[EB/OL] (2017-03-16)[2017-03-03]. http:// http://www.soa.gov.cn/zwgk/ hygb/zghyjjtjgb/2016njjtjgb/201703/t20170322_55285.html

[State Oc- eanic Administration. Bulletin of marine economy statistics of China 2004-2015[EB/OL]. (2017-03-16)[2017-0303]. http://www.soa.gov.cn/zwgk/hygb/zghyjjtjgb/2016njjtjgb/ 201703/t20170322_55285.html]

[2] 孙康, 周晓静, 苏子晓, 等. 中国海洋渔业资源可持续利用的动 态评价与空间分异 [J]. 地理科学, 2016, 36(8): 1172-1179.

[Sun K, Zhou X J, Su Z X, et al. Dynamic assessment and spatial differentiation of sustainable utilization of marine fishery resources in China[J]. Scientia Geographica Sinica, 2016, 36 (8): 1172-1179.]

[3] 肖姍, 孙才志. 基于 DEA 方法的沿海省市海洋渔业经济发展水
平评价 [J]. 海洋开发与管理, 2008,25(4): 90-94. [Xiao S, Sun $\mathrm{C}$ Z. Evaluation of marine fishery economic development in coastal provinces and cities based on DEA model[J]. Ocean Development and Management, 2008,25 (4): 90-94.]

[4] 梁盼盼, 俞立平. 中国渔业经济投人产出绩效分析-基于 19992010 年面板数据的实证 $[J]$. 科技与管理, 2014, 16(2) : 21-26. [Liang P P, Yu L P. Empirical study on the fishery performance in China: based on 1999-2010 panel data[J]. Science-Technology and Management, 2014, 16(2):21-26.]

[5] 于淑华, 于会娟. 中国沿海地区渔业产业效率实证研究-基于 DEA 的 Malmquist 指数分析 [J]. 中国渔业经济, 2012, 30 (3): 140-146. [Yu S H, Yu H J. An empirical study on the coastal areas fishery efficiency in China: based on DEA- Malmquist index[J]. Chinese Fisheries Economics, 2012, 30(3): 140-146.]

[6] 杨卫, 周薇. 基于 DEA 模型的渔业科技生产效率实证分析 [J]. 中国农学通报, 2014, 30 (35) : 139-142. [Yang W, Zhou W. Analysis of the piscatorial science and technology's productive efficiency based on DEA model[J]. Chinese Agricultural Science Bulletin, 2014,30(35): 139-142.]

[7] 徐璐. 我国海洋渔业绿色全要素生产率变动及地区收玫性研 究 [D]. 青岛: 中国海洋大学, 2015. [Xu L. The Research on Change of Green Total Factor Productivity and Convergence of China's Coastal City[D]. Qingdao: Ocean University of China, 2015.]

[8] Gao J, Chen D Q. Effects of fisheries production factors on the sustainable development of Chinese marine fisher economics[J]. Journal of Shanghai Fisheries University, 2003, 12(S1): 86-92.

[9] 张立新, 朱道林, 杜挺, 等. 基于 DEA 模型的城市建设用地利用 效率时空格局演变及驱动因素 [J]. 资源科学, 2017, 39(3): 418- 429. [Zhang L X, Zhu D L, Du T, et al. Spatiotemporal pattern evolvement and driving factors of urban construction land use efficiency using data envelopment analysis[J]. Resources Science, 2017,39(3): 418-429.]

[10] Mankiw G N. Principle of Economics [M]. London: Oxford University Press, 1977.

[11] 官文江, 田思泉, 朱江峰, 等. 渔业资源评估模型的研究现状与 展望 [J]. 中国水产科学, 2013, 20(5): 1112-1120. [Guan W J, Tian S Q, Zhu J F, et al. A review of fisheries stock assessment models[J]. Journal of Fishery Sciences of China, 2013, 20 (5): 1112-1120.]

[12] 陈新军, 刘金立, 官文江, 等. 渔业资源生物经济模型研究及应 用进展 [J]. 上海海洋大学学报, 2014, 23(4): 608-617. [Chen X J, Liu J L, Guan W J, et al. Progress of theory and application of bio-economic model in fishery resources[J]. Journal of Shanghai Ocean University, 2014, 23(4): 608-617.]

[13] 陈作志, 林昭进, 邱永松. 基于 AHP 的南海海域渔业资源可持 续利用评价 [J]. 自然资源学报, 2010, 25(2): 249-257. [Chen Z 
Z, Lin Z J, Qiu Y S. Evaluation of sustainability of fisheries resources for South China Sea based on the AHP[J]. Journal of Natural Resources, 2010,25(2): 249-257.]

[14] 国家农业部, 国家环境保护部. 中国渔业生态环境状况公告 [EB/OL]. (2006-06-08) [2017-03-03]. http://www.cnfm.gov.cn/ zyhbyzj/gbzyhb/200606/t20060608_2643190.htm. [Ministry of Agriculture, Ministry of Environmental Protection. Report on the State of the Fishery Eco- environment in China[EB/OL]. (2006-06-08) [2017-03-03]. http://www.cnfm.gov.cn/zyhbyzj/ gbzyhb/200606/t20060608 2643190.htm.]

[15] 农业部渔业局. 中国渔业统计年鉴[M]. 北京: 海洋出版社, 2004-2015. [Department of Agriculture Fisheries Bureau. China Fisheries Statistics Yearbook[M]. Beijing: Ocean Press, $2004-2015$.

[16] Charnes A, Cooper W W, Rhodes E. Measuring the efficiency of decision making units[J]. European Journal of Operational Research, 1978,2(6):429-444.

[17] 赵林, 张宇硕, 焦新颢, 等. 基于 SBM 和 Malmquist 生产率指数 的中国海洋经济效率评价研究 [J]. 资源科学, 2016, 38(3): 461-475. [Zhao L, Zhang Y S, Jiao X Y, et al. An evaluation of Chinese marine economy efficiency based on SBM and Malmquist productivity indexes[J]. Resources Science, 2016, 38 (3) : 461-475.]

[18] Tone K. A slacks-based measure of efficiency in data envelopment analysis[J]. European Journal of Operational Research, $2001,130(3): 498-509$.

[19] Tone K. Dealing with Undesirable Outputs in DEA: A Slacks Based Measure (SBM) Approach[R]. GRIPS Research Report Series I-2003-0005, 2003.

[20] 赵林, 张宇硕, 吴迪, 等. 考虑非期望产出的中国省际海洋经济 效率测度及时空特征 [J]. 地理科学, 2016, 36 (5) : 671-680. [Zhao L, Zhang Y S, Wu D, et al. Marine economic efficiency and spatio-temporal characteristics of inter-province based on undesirable outputs in China[J]. Scientia Geographica Sinica, 2016,36(5): 671-680.]

[21] 马占新. 数据包络分析模型与方法[M]. 北京: 科学出版社, 2010. [Ma Z X. The Models and Methods on Data Envelopment Analysis[M]. Beijing: Science Press, 2010.]

[22] Chen Z, Kahn M E, Liu Y, et al. The Consequences of Spatially Differentiated Water Pollution Regulation in China[R]. NBER Working Paper No. w22507, 2016.

[23] 山东省环保厅. 山东省环境状况公报 2004-2015[EB/OL] (2016- 05- 17) [2017-03-03]. http://www.shandong.gov.cn/col/ col2861/index.html. [Shandong Provincial Environmental Protection Department. Bulletin of Environmental Conditions of Shandong Province 2004-2015[EB/OL]. (2016- 05-17) [201703-03]. http: //www.shandong.gov.cn/col/col2861/index.html.]
[24] 国家海洋局. 中国海洋环境状况公报 2004-2015[EB/OL]. (2016- 04- 08) [2017- 03- 03]. http: //www.soa.gov.cn/xw/hyyw_ 90/201604/t20160408_50782.html[State Oceanic Administration. Bulletin of China's Marine Environment 2004-2015[EB/OL]. (2016-04-08) [2017-03-03]. http://www.soa.gov.cn/xw/hyyw 90/201604/t20160408 50782.html.]

[25] 广东省环保厅. 广东省环境状况公报 2004-2015[EB/OL]. (2016-06-08) [2017-03-03]. http://www.gdep.gov.cn/hjjce/gb/. [Guangdong Provincial Environmental Protection Department Bulletin of En-vironmental Conditions of Guangdong Province [EB/OL]. (2016-06-08) [2017-03-03]. http://www.gdep.gov.cn/ hjjce/gb/.]

[26] 王洪礼, 倪强, 郭嘉良, 等. 随机梯度的海岸带渔业经济影响因 素分析 [J]. 天津大学学报 (社会科学版), 2011, 13 (3): 202206. [Wang H L, Ni Q, Guo J L, et al. Influence factors analysis of coastal zone fishery based on stochastic gradient regression [J]. Journal of Tianjin University (Social Sciences) , 2011, 13 (3) : 202-206.]

[27] 刘慧媛,陈孟婕,徐硕, 等. 基于灰色关联度分析的我国渔业经 济产值影响因素评价 [J]. 渔业信息与战略, 2014, 29(3): 192198. [Liu H Y, Chen M J, Xu S, et al. Evaluation on total output value and related factors of fishery economy based on grey relational analysis[J]. Modern Fisheries Information, 2014, 29 (3) : 192-198.]

[28] 陈琦, 韩立民. 基于 ISM 模型的中国大洋性渔业发展影响因素 分析 [J]. 资源科学, 2016, 38 (6) : 1088-1098. [Chen Q, Han L M. Analysis of factors influencing high seas fisheries development in China based on Interpretative Structural Modeling[J]. Resources Science, 2016,38(6): 1088-1098.]

[29] 国家海洋局. 中国海洋统计年鉴 [M]. 北京: 海洋出版社, 2004-2015. [ State Oceanic Administration. China Marine Statistical Yearbook[M]. Beijing: Ocean Press, 2004-2015.]

[30] 吴贤荣, 张俊遥, 田云, 等. 中国省域农业碳排放: 测算、效率变 动及影响因素研究-基于 DEA-Malmquist 指数分解方法与 Tobit 模型运用 $[J]$. 资源科学, 2014, 36(1): 129-138. [Wu X R, Zhang J B, Tian Y, et al. Provincial agricultural carbon emissions in China: calcul- ation, performance change and influencing factors[J]. Resources Science, 2014, 36 (1): 129-138.]

[31] Tobin J. Estimation of relationship for limited dependent variables[J]. Econometrica, 1958, 26(1): 24-36

[32] 同春芬, 黄艺. 我国海洋渔业转产转业政策导致的双重困境探 析一从“过度捕捞”到“过度养殖” [J]. 中国海洋大学学报(社会 科学版), 2013,02: 1-7. [Tong Chunfen, Huang Yi. Analysis of the Dilemma Caused by the Policy of Marine Fishery Change in Production and Industry-From "Over- Fishing" to "OverAquaculture"[J]. Journal of Ocean University of China (Social Sciences) , 2013,02:1-7.] 


\title{
Marine fishery economic efficiency and its spatio-temporal differences based on undesirable outputs in China
}

\author{
SUN Kang ${ }^{1}$, JI Jianwen ${ }^{1}$, LI Lidan, ZHANG Chao', LIU Junfeng², FU Min ${ }^{1}$ \\ (1. Center for Studies of Marine Economy and Sustainable Development of Liaoning Normal University, Dalian 116029, China; \\ 2. School of Economics, East China Normal University, Shanghai 200241, China)
}

\begin{abstract}
In view of the fact that the pollution index is not easy to measure, less attention has been paid to the undesirable outputs from the frontier quantitative research on marine fishery economy. In this study, it is assumed the negative effect caused by pollution of marine natural fisheries waters as the undesirable outputs. We adopt SBM (Slacks based measure) model to evaluate the economic efficiency of marine fishery in 11 coastal provincial-level areas of China from 2004 to 2015. Furthermore, we use Kernel density and Tobit model to analyze the spatio-temporal evolution and influencing factors of economic efficiency of marine fishery. The results show that: In the time series perspective, the economic efficiency of marine fishery remains low, indicating that the marine fishery economic restructuring and upgrading has not yet achieved the desirable effect; From the perspective of time and space, the economic efficiency of marine fishery in the study area has shown a polarization trend and has not been effectively improved. This indicates that the level of marine fishery development is unbalanced in China. Generally speaking, the economic efficiency of marine fishery is low, which indicates that marine fishery economic development is relatively slow in China. In terms of industrial structure, the main reason for the low overall economic efficiency of marine fishery is attributed to the high proportion of the primary industry and the low level of technology, suggesting that marine fishery industry structure continues to follow the traditional mode that the primary industry dominates the economy. In order to reverse the negative relationship between the professional level and efficiency of fishermen's employment, it should be improved in quality and efficiency of the transfer industry and employment policy. In the future, marine fishery will face the dual challenges of institutional and structural transformation in China. According to the different resource endowments of coastal areas, firstly, the institutional innovation should hold a leading position in the transformation and upgrading of the system. Secondly, it is urgent to develop a differentiated and innovative development path. To improve the economic efficiency of marine fishery, we should adjust the industrial structure and optimize the regional layout.
\end{abstract}

Key words : marine fishery economic efficiency; undesirable outputs; SBM model; kernel density; Tobit model 